\title{
Hepatitis B Virus and Hepatitis C Virus Co-infection: An Evaluation of Eighty-Two Patients
}

\author{
Hepatit B ve Hepatit C Virüs Koenfeksiyonu: Seksen Iki Hastanın Değerlendirilmesi
}

\author{
Bilgehan AYGEN1, Özgür GÜNAL2, Orhan YILDIZ1, Mustafa Kemal ÇELEN3, Sıla AKHAN4, \\ Şener BARUT5, Celal AYAZ3 \\ 1 Erciyes University Faculty of Medicine, Department of Infectious Diseases and Clinical Microbiology, Kayseri, Turkey \\ 2University of Health Sciences, Samsun Training and Research Hospital, Clinic of Infectious Diseases and Clinical Microbiology, Samsun, Turkey \\ ${ }^{3}$ Dicle University Faculty of Medicine, Department of Infectious Diseases and Clinical Microbiology, Diyarbakır, Turkey \\ ${ }^{4}$ Kocaeli University Faculty of Medicine, Department of Infectious Diseases and Clinical Microbiology, Kocaeli, Turkey \\ ${ }^{5}$ Gaziosmanpaşa University Faculty of Medicine, Department of Infectious Diseases and Clinical Microbiology, Tokat, Turkey
}

\begin{abstract}
Objective: In this study, we aimed to investigate the characteristics and treatment results of 82 co-infected patients with hepatitis B virus (HBV)/hepatitis $\mathrm{C}$ virus (HCV).

Materials and Methods: Four university hospitals evaluated HBV/HCV co-infection cases retrospectively. We analyzed the epidemiological, virological, clinical, and histopathological data and the results of treatment in patients co-infected with HBV and HCV. Pegylated interferon (peg IFN) plus ribavirin treatment was given to patients with HCV dominance. The results of patients receiving different treatment for HBV were evaluated.

Results: The mean age of the patients was $44.3 \pm 14.7$ years and $52.4 \%$ were female. The major risk factors were dental therapy, any surgical procedure, hemodialysis, and blood transfusion. The average HCV RNA level and HBV DNA level were found to be $1.36 \times 10^{6} \pm 3.06 \times 10^{6}$ $\mathrm{IU} / \mathrm{mL}$, and $1.55 \times 10^{7} \pm 4.83 \times 10^{7} \mathrm{IU} / \mathrm{mL}$, respectively. On histopathology, the mean grade of necroinflammation was found to be $4.9 \pm 2.6$ while the mean stage of fibrosis was $1.7 \pm 1.5$ in 39 patients. $8.5 \%$ of patients were positive for both HCV-RNA and HBVDNA positive and in $85.7 \%$ of cases, HCV infection was found to be dominant. The rate of sustained virologic response was $70.8 \%$ in 24 patients receiving peg IFN plus ribavirin therapy. Reactivation of HBV was found in $33.3 \%$ of cases. HBV DNA was negative in all patients who received oral antiviral therapy.

Conclusion: In cases where both HCV RNA and HBV DNA were positive, HCV was predominant. This is especially noticeable in hemodialysis patients

Keywords: Hepatitis B virus, hepatitis C virus, co-infection, epidemiology, treatment
\end{abstract}

OZZ

Amaç: Bu çalışmada, 82 hepatit $B$ virüs (HBV)/hepatit $C$ virüs $(\mathrm{HCV})$ ko-enfekte hastanın özelliklerini ve tedavi sonuçlarını araştırmayı amaçladık.

Gereç ve Yöntemler: Dört farklı üniversite hastanesinde HBV/HCV ko-enfeksiyonu olan hastalar retrospektif olarak incelendi. HBV/ HCV ko-enfeksiyonu olan hastaların epidemiyolojik, virolojik, klinik, histopatolojik verileri ve tedavi sonuçları analiz edildi. HCV enfeksiyonu dominansı olan hastalara pegile interferon (peg IFN) ve ribavirin tedavisi verildi. HBV enfeksiyonu için farklı tedaviler alan hastaların sonuçlarıda değerlendirildi.

Bulgular: Hastaların yaş ortalaması $44,3 \pm 14,7$ idi ve $\% 52,4$ 'ü kadın hasta idi. HCV enfeksiyonu için major risk aktörleri; diş tedavisi, cerrahi girişim, hemodiyaliz ve kan transfüzyonu idi. Ortalama HCV RNA seviyesi $1,36 \times 10^{6} \pm 3,06 \times 10^{6} \mathrm{IU} / \mathrm{mL}$, ortalama HBV DNA seviyesi $1,55 \times 10^{7} \pm 4,83 \times 10^{7} \mathrm{IU} / \mathrm{mL}$ olarak saptandı. Biyopsi yapılan 39 hastanın histopatolojik incelemesinde nekroenflamatuvar aktivitesi ortalama $4,9 \pm 2,6$ iken, fibrozis evresi otalama $1,7 \pm 1,5$ olarak saptand. Hastaların \%8,5'inde hem HCV-RNA hem de HBV-DNA pozitifti ve bu hastaların \%85,7'sinde HCV enfeksiyonu dominant olarak bulundu. Hastalardan 24 tanesine peg IFN + ribavirin tedavisi başlandı ve bu hastalarda kalıcı viral yanıt oranı $\% 70,8$ olarak saptandı. Hastalarının \%33,3'ünde HBV reaktivasyon gelişti. Oral antiviral tedavi başlanan hastaların tümünde HBV DNA negatifleşti. Sonuç: Hem HCV RNA hem de HBV DNA'nın pozitif olduğu durumlarda, HCV baskıntı. Bu durum özellikle hemodiyaliz alan hastalarda belirgindi.

Anahtar Kelimeler: Hepatit B virüs, hepatit C virüs, ko-enfeksion, epidemiyoloji, tedavi

Aygen B, Gunal 0, Yildiz O, Celen MK, Akhan S, Barut S, Ayaz C. Hepatitis B Virus and Hepatitis C Virus Co-infection: An Evaluation of Eighty-Two Patients. Viral Hepat J. 2017;23:14-19. 


\section{Introduction}

Hepatitis B virus (HBV) and hepatitis C (HCV) virus infections are among the most common causes of advanced chronic liver disease worldwide. Patients co-infected with HBV and HCV have higher rates of progression, faster fibrosis, more severe liver disease, and are at a significantly increased risk of developing hepatocellular carcinoma (HCC) compared to those mono-infected with $\mathrm{HBV}$ or $\mathrm{HCV}(1,2,3)$. Co-infection with $\mathrm{HBV} / \mathrm{HCV}$ is rare and epidemiology is not fully defined $(4,5)$. It is estimated that there are about 7-20 million co-infected patients worldwide (6). According to study reports, approximately 5-7\% of HBV-infected patients also were positive for anti-HCV and $2-10 \%$ of chronic hepatitis C virus $(\mathrm{CHC})$ patients were positive for $\mathrm{HBsAg}(4,7)$. In one Turkish Study, 10.165 hepatitis cases were evaluated in 10 hospitals and the co-infection rate was found to be $974 / 100.000$ (8). Combined chronic infection with $\mathrm{HBV}$ and $\mathrm{HCV}$ is common in areas endemic for either viruses. HCV superinfection in patients with chronic HBV infection is one of the most common clinical conditions in AsianPacific countries where co-infection is common (4).

Until this time, there was no standard maintenance recommendation for $\mathrm{HBV} / \mathrm{HCV}$ co-infection $(1,5,9)$. Pegylated interferon (peg IFN) and ribavirin combination therapy demonstrated similar efficacy in suppressing HCV RNA in co-infected and $\mathrm{HCV}$ mono-infection cases. However, re-activation of HBV during therapy is an important question $(3,4,5,10)$.

This retrospective, multicenter study aimed to investigate the epidemiological, virological, clinical, and histopathological characteristics and treatment results and the change in the status of $\mathrm{HBV}$ or $\mathrm{HCV}$ infection following treatment in 82 co-infected patients with HBV/HCV in Turkey.

\section{Materials and Methods}

\section{Study population and data collection}

In this study, four university hospitals retrospectively evaluated a total of 82 patients aged 18 years and over with $\mathrm{HBV} / \mathrm{HCV}$ co-infection. Ethical approval was not required as the study was a retrospective study. This study included patients who were followed-up between 1998 and 2012 and with regular records. The $\mathrm{HBV} / \mathrm{HCV}$ co-infected patients were diagnosed by serum HBsAg, antibodies to HCV, detectable serum HCV RNA and/or HBV DNA, and compensated liver disease. Data was collected using case records from the doctors in charge in the hospitals involved. We obtained baseline clinical and virological characteristics and results of treatment with the help of retrospective review of medical records, and available histological data before treatment were also recorded. Participant's demographic data, year of diagnosis, the possible transmission routes of viruses, alanine aminotransferase (ALT) levels, markers of hepatitis, results of HCV RNA and HBV DNA tests and the liver biopsy, and treatment results were all evaluated. We analyzed the epidemiological, virological, clinical, and histopathological data and the results of treatment in patients co-infected with HBV and HCV.

Laboratory tests were performed at each hospital. ALT tests were performed with automatic devices. Serological markers (anti$\mathrm{HCV}, \mathrm{HBsAg}$, anti-HBs, HBeAg, anti-HBe and anti-HBc) were tested with different enzyme immunoassay kits. HBV DNA and HCV RNA were investigated by using real-time polymerase chain reaction
(RT-PCR) with different kits [Cobas Ampliprep/Cobas TaqMan HBV/ $\mathrm{HCV}$ assay (Roche, Molecular System, Pleasanton, CA], Abbott RealTime HBV/HCV assay (Abbott Diagnostics, Chicago, IL), HBV/ HCV QS-RGQ (Qiagen, Hilden, Germany). All results were converted to $\mathrm{IU} / \mathrm{mL}$. Liver biopsy specimens were scored according to the Ishak's Scoring System (11). The mean grade of necroinflammation and the stage of fibrosis were evaluated. The HCV genotype was determined by different methods [sequence analysis (Pyromark Qiagen-Germany), RT-PCR Fluorion HCV genotyping 1.0 (lontek AŞ, Istanbul, Turkey)] in patients receiving HCV treatment.

\section{Definition, treatment and evaluation of the treatment responses}

Peg IFN- $\alpha 2$ 2a plus ribavirin or peg IFN- $\alpha 2 b$ plus ribavirin treatment was given to $\mathrm{HCV}$ dominant patients. Current guidelines were used to determine dose modification and initial dosage of treatment drug $(12,13)$. Patients with genotype 1 or genotype 4 were treated for 48 weeks. All subjects were followed up at least for 24 weeks after cessation of therapy. Responses to therapy were defined according to the American Association for the Study of Liver Diseases guideline (12). The categories and severity of adverse events were registered. HBV DNA was measured at baseline, at week 24 and at week 48 during therapy in all patients. We evaluated the results of patients receiving different treatments for HBV. All patients continued with the antiviral therapy and were followed up at three to six month intervals.

\section{Statistical Analysis}

We expressed the clinical and biochemical characteristics of the patients as mean \pm standard deviation. Statistical analyses were performed with the Mann-Whitney $U$ test and chi-square test. A p value of less than 0.05 was considered statistically significant. The SPSS (version 16.0) software package was used for statistical analysis.

\section{Results}

\section{Demographics and baseline characteristics}

The evaluated data were collected from four different academic hospitals in four different regions. $52.4 \%$ of patients were female and the mean age of the patients was $44.3 \pm 14.7$ years. The regional distribution of co-infection was as follows: $41.5 \%$ in the Central Anatolian Region, 37.8\% in the Southeast Region, $18.3 \%$ in the Black Sea Region, and $2.4 \%$ in the Marmara Region. Dental therapy, any surgical procedure, hemodialysis and blood transfusion were the major risk factors. Patients' characteristics are summarized in Table 1.

The mean ALT level was 47.8 $239.0 \mathrm{IU} / \mathrm{L}$. HBeAg was positive in $14.6 \%$ of patients. Of the 82 patients with co-infection, 36 (43.9\%) were HCV RNA-positive, while 46 (56.1\%) were HBV DNA-positive. HCV RNA levels were found to be between 170 and $1.62 \times 10^{7} \mathrm{IU} / \mathrm{mL}$ and the average HCV RNA level was found to be $1.36 \times 10^{6} \pm 3.06 \times 10^{6} \mathrm{IU} / \mathrm{mL}$. Twenty-eight of the 36 patients (77.8\%) had a HCV RNA level of less than $600.000 \mathrm{IU} / \mathrm{mL}$. HBV DNA levels were between 50 and $1.70 \times 10^{8} \mathrm{IU} / \mathrm{mL}$ and the average HBV DNA level was found to be $1.55 \times 10^{7} \pm 4.83 \times 10^{7} \mathrm{IU} / \mathrm{mL}$. Twenty-two of the 46 patients (47.8\%) had a HBV DNA level of less than $2.000 \mathrm{IU} / \mathrm{mL}$. Liver biopsy was performed in 39 patients. 
The mean stage of fibrosis was $1.7 \pm 1.5$, and the mean grade of necroinflamation was $4.9 \pm 2.6$ on histopathology.

Both HCV-RNA and HBV-DNA were positive in $8.5 \%$ of patients $(n=7)$ and $\mathrm{HCV}$ infection was dominant in $85.7 \%$ of cases. In the HCV RNA and HBV DNA-positive group, 5 patients had high ALT levels. HCV RNA levels were in the range of 1139-2.40×106 (average: $\left.6.24 \times 10^{5} \pm 8.38 \times 10^{5}\right) \mathrm{IU} / \mathrm{mL}$ in 7 patients. HBV DNA levels were $211-5.60 \times 10^{6}$ (average: $8.09 \times 10^{5} \pm 2.12 \times 106$ ) $\mathrm{IU} / \mathrm{mL}$ in these patients. In 1 patient, HBV DNA level was $5.607 .835 \mathrm{IU} / \mathrm{mL}$ with low level of HCV RNA (1139 IU/mL). Hemodialysis was the most important risk factor in 2 of s7 cases (28.6\%). Serum HCV RNA levels were compared between patients with and without detectable serum HBV DNA. HCV RNA levels were higher in

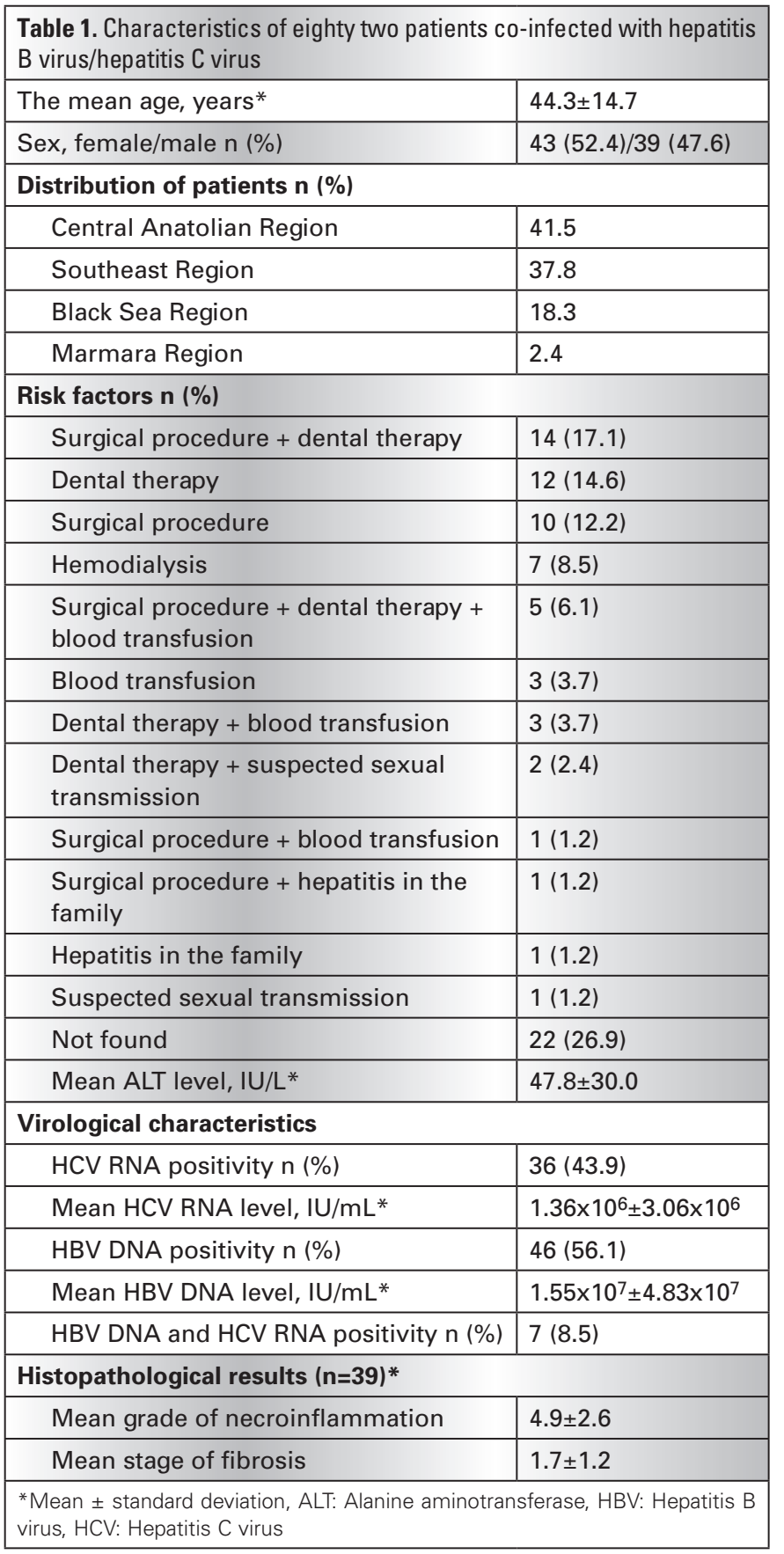

patients with detectable HBV DNA $\left(6.24 \times 10^{5} \pm 8.38 \times 10^{5} \mathrm{IU} / \mathrm{mL}\right)$ than in patients without detectable HBV DNA $\left(1.53 \times 10^{3} \pm 3.38 \times 10^{6}\right.$ $\mathrm{IU} / \mathrm{mL})$. We did not find any statistical significance $(\mathrm{p}=0.969)$.

\section{Treatment efficacy}

Thirty-four patients had received treatment and in 25 of these, liver biopsy was performed. Peg IFN plus ribavirin therapy was given to 27 patients with dominant HCV infection (peg IFN- $\alpha$ 2a in 12 patients and peg IFN- $\alpha 2 b$ in 15 patients). Among patients who received peg IFN plus ribavirin therapy, 25 had HCV genotype 1 and 2, HCV genotype 4. Different treatment regimens were given to 7 patients with dominant HBV infection.

The mean ALT level was $73.4 \pm 53.8 \mathrm{IU} / \mathrm{L}$ and the mean HCV RNA level was $1.43 \times 10^{6} \pm 3.16 \times 10^{6} \mathrm{IU} / \mathrm{mL}$ in group receiving peg IFN plus ribavirin therapy. HCV RNA and HBV DNA were positive in 3 patients. Two of the 3 patients had a baseline HBV DNA level of less than $2000 \mathrm{IU} / \mathrm{mL}$ (292 and $403 \mathrm{IU} / \mathrm{mL}$ ) and the HBV DNA level was $2400 \mathrm{IU} / \mathrm{mL}$ in 1 patient. Liver biopsy was performed in 18 patients, and the mean grade of necroinflammation was $5.3 \pm 1.8$ while the mean stage of fibrosis was $1.8 \pm 1.3$ in this group. Three patients were excluded since 1 patient could not tolerate medications and 2 were lost-to-follow-up. In 24 patients, the rate of early virologic response (EVR), end-of-treatment response (ETR), and sustained virologic response (SVR) was $83.3 \%, 79.2 \%$, and, $70.8 \%$, respectively. Relapse was observed in 3 patients $(12.5 \%) .7$ patients $(29.2 \%)$ did not respond to treatment. One of the patients had EVR and two had EVR and ETR (Table 2).

Disappearance of HBV DNA occurred in 1 of 3 (33.3\%) patients with positive HBV DNA at baseline. HBV DNA level of above 2000 $\mathrm{IU} / \mathrm{mL}(2400 \mathrm{IU} / \mathrm{mL})$ and SVR was not observed in this patient. After completion of treatment, serum HBV DNA levels remained

Table 2. Characteristics of patients treated with pegylated interferon and ribavirin

\begin{tabular}{|c|c|}
\hline The number of patients & 27 \\
\hline \multicolumn{2}{|l|}{ HCV genotype $n(\%)$} \\
\hline Genotype 1 & $25(92.6)$ \\
\hline Genotype 4 & $2(7.4)$ \\
\hline Mean ALT level, IU/L* & $73.4 \pm 53.8$ \\
\hline Mean HCV RNA level, IU/mL* & $1.43 \times 10^{6} \pm 3.16 \times 10^{6}$ \\
\hline \multicolumn{2}{|l|}{ Histopathological results $(n=18) *$} \\
\hline Mean grade of necroinflammation & $5.3 \pm 1.8$ \\
\hline Mean stage of fibrosis & $1.8 \pm 1.3$ \\
\hline \multicolumn{2}{|l|}{ Results of treatment $\mathbf{n}(\%) * *$} \\
\hline EVR & $20(83.3)$ \\
\hline ETR & $19(79.2)$ \\
\hline SVR & $17(70.8)$ \\
\hline Nonresponder & $7(29.2)$ \\
\hline Relapse & $3(12.5)$ \\
\hline Disappearance of HBV DNA & $1(33.3)$ \\
\hline Reactivation of HBV DNA & $7(33.3)$ \\
\hline \multicolumn{2}{|c|}{$\begin{array}{l}\text { *Mean } \pm \text { standard deviation, }{ }^{*} \text { Three patients were excluded, ALT: Alanine } \\
\text { aminotransferase; EVR: Early virological response; ETR: End of treatment } \\
\text { response; SVR: Sustained virological response, HCV: Hepatitis C virus, HBV } \\
\text { Hepatitis B virus }\end{array}$} \\
\hline
\end{tabular}


positive with the same baseline values in another two patients. Interestingly, 7 of 21 (33.3\%) patients with negative HBV DNA at baseline had reactivation of HBV DNA at the 24th week of follow-up; this was not accompanied by significant hepatic flares. The reactivation rate of HBV DNA (50\%) with HCV SVR was the same in patients without SVR $(50 \%)(p=1)$. Serum ALT levels were normal in 4 patients. Serum ALT levels were elevated in 3 patients (mean value: $124 \pm 30.0 \mathrm{IU} / \mathrm{L}$; range: 89-161 $\mathrm{IU} / \mathrm{L}$ ), and tenofovir disoproxil fumarate were given to these 3 patients. After three months, the serum HBV DNA of these patients became undetectable and the ALT levels returned to normal.

The mean ALT level was $94.1 \pm 46.9 \mathrm{IU} / \mathrm{L}$ and the mean HBV DNA level was found to be $4.86 \times 10^{7} \pm 8.29 \times 10^{7} \mathrm{IU} / \mathrm{mL}$ in group receiving treatment for $\mathrm{HBV}$ infection. $\mathrm{HCV}$ RNA and $\mathrm{HBeAg}$ were negative in this group. In 7 patients, the mean stage of fibrosis was $2.9 \pm 1.1$ and the mean grade of necroinflammation was $6.9 \pm 1.2$. HBV DNA was found to be negative in all patients who had received oral antiviral therapy. HBV DNA was negative in two patients at the end of the $12^{\text {th }}$ month of lamivudine therapy. HBV DNA was negative in 4 patients treated with entecavir or tenofovir on the $6^{\text {th }}$ month and $12^{\text {th }}$ month of treatment. None of these patients developed HBV reactivation till date. HBV DNA was positive in 1 patient treated with peg IFN alpha-2a at the $6^{\text {th }}$ month, and therapy was stopped. During the treatment, HBsAg clearance and HCV RNA positivity were not observed in the patients.

During treatment with peg IFN and ribavirin, and oral antiviral agents, severe side effects were not observed. Anemia (hemoglobin level $<10 \mathrm{~g} / \mathrm{dL}$ ) occurred in 2 patients and the ribavirin dose was reduced to $600 \mathrm{mg} /$ day in these patients.

\section{Discussion}

$\mathrm{HBV} / \mathrm{HCV}$ co-infection is common among persons at high endemic areas due to common transmission routes and high risk for parenteral infections $(4,14)$. The worldwide prevalence of $\mathrm{HBV} / \mathrm{HCV}$ co-infection is unknown $(4,5,6,15)$. In an Eastern Europe study of 2200 healthy individuals randomly selected, the rate of co-infection was found to be $0.68 \%$ (16). The rate of HCV co-infection in chronic HBV patients ranges from $9 \%$ to $30 \%$, depending on geographical area (17). The rate of HBV/HCV co-infection was found to be more common in patients over 50 years of age and increased with age in an Italian study (18). These numbers may not reflect the truth, as both were not large-scale studies and concealed infections have not been well-recognized (occult HBV infection) (19). Data related to HCV/HBV co-infection are lacking in Turkey. In one Turkish study, the co-infection rate was reported to be $974 / 100.000$ (8). These results show that the prevalence of $\mathrm{HBV}$ or HCV mono-infection is higher than HBV/HCV co-infection.

Organ transplant recipients, patients with human immunodeficiency virus infection, hemodialiysis patients, and intravenous drug users are often at high risk of $\mathrm{HBV} / \mathrm{HCV}$ co-infection (20). The most common type of HBV/HCV co-infection is $\mathrm{HCV}$ superinfection in indivudials with chronic hepatitis $\mathrm{B}$ virus $(\mathrm{CHB})$ in areas with high prevalence of HBV infections $(4,21)$. Dental therapy, surgical interventions, hemodialysis and blood transfusion, which are identified as risk factors in this study, reflect the epidemiological differences among the other countries. Zhang et al. (22) reported that the clinical characteristics of $\mathrm{HBV} / \mathrm{HCV}$ infected patients were significantly different from those of $\mathrm{HCV}$ infected patients in different ways.

Epidemiological studies on viral interaction have not revealed consistent results. Some reported no interaction; others reported a sub/supra-additive or multiplicative interaction (10). Additionally, most clinical observations suggest that the interaction between both viruses is often characterized by the inhibition of HCVmediated HBV replication $(4,8)$. On the other hand, follow-up studies have shown that the virological patterns in co-infection cases had dynamic profiles over time and were widely divergent (4). Coffin et al. (23) has published a case report of profound suppression of $\mathrm{CHC}$ after superinfection with $\mathrm{HBV}$ and establishment of $\mathrm{CHB}$. It was hypothesized that HBV infection precipitated generalized and/or virus-specific cellular immune responses that profoundly suppressed HCV replication and yet failed to inhibit progression to $\mathrm{CHB}$. Without evidence for direct interference in vitro, HBV and HCV can replicate in the same cell (23). In our study, HCV RNA was not higher in patients without detectable serum HBV DNA. However, the difference in the number of patients may have led to this conclusion. HCV-RNA and HBV-DNA were positive in 7 patients and $\mathrm{HCV}$ infection was dominant in 6 of the 7 patients. Since HCV is the common cause of infection in patients receiving hemodialysis, the present finding may be due to the high prevalence of HCV hemodialysis and this is especially noticeable in hemodialysis patients (24). It has been reported by Lee et al. (25) that HCV infection suppressed the serum HBV DNA level in hemodialysis patients. In this study, it was found that $\mathrm{HBV} / \mathrm{HCV}$ co-infection, in comparison with single HBV infection, did not cause more severe liver diseases or reduced patient survival in hemodialysis patients during a 10-year follow-up. For this reason, the viral interference observed in co-infected patients is probably because of indirect mechanisms mediated by innate and/or adaptive host immune responses (26).

Those infected with HBV/HCV tend to have more severe liver injury, a higher likelihood of liver cirrhosis, hepatic decompensation, and a higher incidence of HCC when compared to mono-infected patients $(4,5,14)$. In our study, only 39 patients underwent biopsy and none of these patients had advanced fibrosis. However, the severity of fibrosis in infected patients with $\mathrm{HBV} / \mathrm{HCV}$ could not be assessed due to the small sample size of the study. The follow-up period was not long enough in our patients. Therefore, evaluation of $\mathrm{HCC}$ development or advanced cirrhosis in HBV/HCV co-infected patients was not possible, thus, further studies are needed.

While there are well-established treatment modalities for $\mathrm{CHB}$ and $\mathrm{CHC}$ patients, currently, there is no standard treatment for patients infected with $\mathrm{HBV} / \mathrm{HCV}$. In general, the same treatment criteria should be applied to HBV/HCV patients and mono-infected patients. According to recent studies, there is no significant difference in the rapid virologic response, EVR and SVR rates between $\mathrm{HCV}$ monoinfected individuals with peg IFN plus ribavirin treatment and those infected with $\mathrm{HBV} / \mathrm{HCV}$. Yu et al. (27) studied combination therapy with peg IFN- $\alpha 2 a$ and ribavirin for 24-48 weeks, based on different HCV genotypes in 50 co-infected patients, compared to a control group of HCV-mono-infected patients. The researchers found that patients with the $\mathrm{HCV}$ genotype 1 in the co-infection group had a higher rate of partial EVR, ETR and recurrence. However, no significant difference 
was seen in the SVR rates. Kim et al. (28) treated 18 patients co-infected with HCV/HBV with combination peg IFN- $\alpha$ 2a and ribavirin. This study reported a SVR rate of $72 \%$ in all patients, and $60 \%$ and $87.5 \%$ in genotypes 1 and 2, respectively. In our study, the overall SVR rate was found to be $70.8 \%$ in the HBV/ HCV co-infection group with genotype 1 and genotype 4. The relapse rate was $12.5 \%$. The vast majority of Turkish patients with $\mathrm{CHC}$ have genotype 1 (29). Successful treatment of $\mathrm{CHC}$ infection may correlate with HBV reactivation and flaring $(4,6,30,31)$. In our study, the reactivation rate of HBV infection was $33.3 \%$, however, severe HBV flares were not observed. It was reported by Chuang et al. (32) that co-infected patients who achieved a SVR (compared $\mathrm{HCV}$ non-responders) were more likely to have reactivation of HBV (58.8\% vs. $12.5 \%$ ) or HBV flares (44.8\% vs. $8.3 \%$ ), and less likely to achieve HBV DNA clearance (8.3\% vs. $100 \%)$. Yu et al. (27) found that the reactivation rate of HBV DNA (33.3\%) with HCV SVR was significantly higher than that in patients without SVR (8.7\%). In our study, the HBV DNA reactivation rate was $33.3 \%$ and there was no difference between with or without HCV SVR. Given this risk of HBV reactivation, clinicians must be cautious while treating co-infected patients with the combination of IFN and ribavirin.

There have been not any published studies regarding treatment of co-infected patients with the newer agents adefovir, entecavir and tenofovir. Marrone et al. (33) published a study of lamivudine with IFN for co-infected patients in which eight patients with dually active HBV and HCV were treated with $5 \mathrm{MU}$ IFN and lamivudin (LAM) $100 \mathrm{mg} /$ day for 12 months followed by LAM alone for 6 months. Three patients had clearance of HBV DNA (37.5\%) and 3 had clearance of $\mathrm{HBeAg}$. In addition, 4 patients $(50 \%)$, persistent for 12 months post-treatment, also had clearance of HCV RNA (33). In our study, HBV DNA was found to be negative in all patients who received oral antiviral therapy, however, HBsAg clearance was not observed. HBeAg was negative in all patients receiving therapy.

It has been reported that the majority of Turkish patients with $\mathrm{CHB}$ were $\mathrm{HBeAg}$ negative (34). On the other hand, particularly in patients with $\mathrm{HBV}$-dominant disease, oral antiviral agents may be useful.

For co-infected patients with double-active $\mathrm{HBV} / \mathrm{HCV}$, the addition of peg IFN- $\alpha$ and ribavirin oral nucleotide analogues seems to be a reasonable empirical option, but maintains optimal treatment regime uncertainty $(1,4,5)$.

\section{Conclusion}

We found that the majority of the risk factors for HBV and HCV infected patients were; hemodialysis, blood transfusion, a surgical procedure, and dental treatment. In addition, $\mathrm{HCV}$ is predominant in cases where both HBV DNA and HCV RNA are positive. This was especially noticeable in hemodialysis patients in our study. At present, peg IFN plus ribavirin should be the treatment of choice in patients with dominant $\mathrm{HCV}$ replication. In addition, reactivation of HBV may occur after elimination of $\mathrm{HCV}$, and therefore, close monitoring is recommended for both viruses even for patients with suppressed HBV DNA.

\section{Study Limitations}

The study was conducted before the start of the use of new treatments.

\section{Ethics \\ Informed Consent: A retrospective study. \\ Peer-review: Externally and Internally peer-reviewed.}

\section{Authorship Contributions}

Surgical and Medical Practices: B. A., Ö.G., O.Y., M.K.Ç., S.A., S..B., C.A., Concept: B.A., O.Y., Design: B.A., O.Y., Data Collection or Processing: B.A., Ö.G., O.Y., M.K.Ç., S.A., Ş.B., C.A., Analysis or Interpretation: B.A., O.Y., Literature Search: M.K.Ç., Ş.B., C.A., Writing: B.A., Ö.G., O.Y.

Conflict of Interest: No conflict of interest was declared by the authors.

Financial Disclosure: The authors declared that this study received no financial support.

\section{References}

1. Crockett SD, Keeffe EB. Natural history and treatment of hepatitis $B$ virus and hepatitis C virus coinfection. Ann Clin Microbiol Antimicrob. 2005;4:13

2. Lee LP, Dai CY, Chuang WL, Chang WY, Hou NJ, Hsieh MY, Lin ZY, Chen SC, Hsieh MY, Wang LY, Chen TJ, Yu ML. Comparison of liver histopathology between chronic hepatitis $C$ patients and chronic hepatitis B and C-coinfected patients. J Gastroenterol Hepatol. 2007;22:515-517.

3. European Association for the Study of the Liver. EASL clinical practice guidelines: Management of chronic hepatitis B virus infection. J Hepatol. 2012:57:167-185.

4. Chu CJ, Lee SD. Hepatitis B virus/hepatitis C virus coinfection: epidemiology, clinical features, viral interactions and treatment. J Gastroenterol Hepatol. 2008;23:512-520.

5. Jamma S, Hussain G, Lau DT. Current concepts of HBV/HCV coinfection: coexistence, but not necessarily in harmony. Curr Hepat Rep. 2010;9:260-269

6. Potthoff A, Manns MP, Wedemeyer H. Treatment of HBV/HCV coinfection. Expert Opin Pharmacother. 2010;11:919-928.

7. Peters MG. Special populations with hepatitis B virus infection. Hepatology. 2009;49(Suppl 5):S146-155.

8. Aygen B, Celen Mk, Koksal I, Tosun S, Karabay O, Yamazhan T, Yıldız O, Ayaz C, Tabak F. The prevalence and epidemiological characteristics of hepatitis $B$ virus and hepatitis $C$ virus coinfection in Turkey. Turkiye Klinikleri J Med Sci. 2013;33:1245-1249.

9. Matsuoka S, Nirei $\mathrm{K}$, Tamura A, Nakamura $\mathrm{H}$, Matsumura $\mathrm{H}$, Oshiro S, Arakawa Y, Yamagami H, Tanaka N, Moriyama M. Influence of occult hepatitis B virus coinfection on the incidence of fibrosis and hepatocellular carcinoma in chronic hepatitis C. Intervirology. 2008;51:352-361.

10. Cho Ly, Yang Jj, Ko Kp, Park B, Shin A, Lim MK, Oh JK, Park S, Kim YJ, Shin HR, Yoo KY, Park SK. Coinfection of hepatitis B and $C$ viruses and risk of hepatocellular carcinoma: systematic review and meta-analysis. Int J Cancer. 2011;128:176-184.

11. Ishak K, Baptista A, Bianchi L, Callea F, De Groote J, Gudat F, Denk $\mathrm{H}$, Desmet V, Korb G, MacSween RN, et al. Histological grading and staging of chronic hepatitis. J Hepatol. 1995;22:696-699.

12. Ghany Mg, Strader Db, Thomas DI, Seeff Lb. AASLD practice guidelines. Diagnosis, management, and treatment of hepatitis C: an update. Hepatology. 2009;49:1335-1374.

13. European Association for the Study of the Liver. EASL Clinical Practice Guidelines: management of hepatitis C virus infection. J Hepatol. 2011;55:245-264.

14. Perumalswami PY, Bini EJ. Epidemiology, naturel history, and treatment of hepatitis $B$ virus and hepatitis $C$ virus coinfection. Minerva Gastroenterol Dietol. 2006:52:145-155. 
15. Saravanan $S$, Velu $V$, Nandakumar $S$, Madhavan $V$, Shanmugasundaram $U$, Murugavel KG, Balakrishnan $P$, Kumarasamy N, Solomon S, Thyagarajan SP. Hepatitis B virus and hepatitis $C$ virus dual infection among patients with chronic liver disease. J Microbiol Immunol Infect. 2009;42:122-128.

16. Atanasova MV, Haydouchka IA, Zlatev SP, Stoilova YD, Iliev YT, Mateva NG. Prevalence of antibodies against hepatitis $C$ virus and hepatitis B coinfection in healthy population in Bulgaria. A seroepidemiological study. Minerva Gastroenterol Dietol. 2004;50:89-96.

17. Liaw YF. Role of hepatitis $C$ virus in dual and triple hepatitis virus infection. Hepatology. 1995;22:1101-1108.

18. Gaeta Gb, Stornaiuolo G, Precone Df, Lobello S, Chiaramonte M, Stroffolini T, Colucci G, Rizzetto M. Epidemiological and clinical burden of chronic hepatitis B virus/hepatitis C virus infection. A multicenter Italian study. J Hepatol. 2003;39:1036-1041.

19. Zignego AL, Fontana R, Puliti S, Barbagli S, Monti M, Careccia G, Giannelli F, Giannini C, Buzzelli G, Brunetto MR, Bonino F, Gentilini P. Relevance of inapparent coinfection by hepatitis $B$ virus in alpha interferon-treated patients with hepatitis $C$ virus chronic hepatitis. J Med Virol. 1997;51:313-318.

20. Liaw YF, Chen YC, Sheen IS, Chien RN, Yeh CT, Chu CM. Impact of acute hepatitis $C$ virus superinfection in patients with chronic hepatitis B virus infection. Gastroenterology. 2004;126:10241029.

21. Liaw YF, Lin SM, Sheen IS, Chu CM. Acute hepatitis C virus superinfection followed by spontaneous $\mathrm{HBeAg}$ seroconversion and HBsAg elimination. Infection. 1991;19:250-251.

22. Zhang $K$, Cao $H$, Yang XA, Hong XL, Chen LB, Shu X, Li G, Xu $\mathrm{QH}$. Comparative study on the clinical characteristics of HBV/ $\mathrm{HCV}$ co-infection patients with different $\mathrm{HCV}$ contaminnation mode. Zhonghua Shi Yan He Lin Chuang Bing Du Xue Za Zhi. 2011;25:301-303

23. Coffin CS, Mulrooney-Cousins PM, Lee SS, Michalak TI, Swain MG. Profound suppression of chronic hepatitis C following superinfection with hepatitis B virus. Liver Int. 2007;27:722-726.

24. Bozkurt I, Aygen B, Gokahmetoğlu S, Yildiz O. Occult HCV infection in hemodialysis patients. In: 18th International Symposium on Hepatitis C Virus and Related Viruses; 2011 Sept 8-12; Seattle, Washington: European Association for the Study of the Liver, 2011:253.
25. Lee CC, Li IJ, Chen YC, Cheng JW, Wu HH, Weng CH, Fang JT, Tian YC. Comparable ten-year outcome in hemodialysis patients with hepatitis $C$ virus and hepatitis $B$ virus coinfection and single hepatitis B virus infection. Blood Purif. 2011;32:89-95.

26. Bellecave P, Gouttenoire J, Gajer M, Brass V, Koutsoudakis G, Blum HE, Bartenschlager R, Nassal M, Moradpour D. Hepatitis $B$ and $C$ virus coinfection: a novel model system reveals the absence of direct viral interference. Hepatology. 2009;50:46-55.

27. Yu JW, Sun LJ, Zhao YH, Kang P, Gao J, Li SC. Analysis of the efficacy of treatment with peginterferon $\alpha-2 a$ and ribavirin in patients coinfected with hepatitis B virüs and hepatitis $C$ virüs. Liver Int. 2009;29:1485-1493.

28. Kim YJ, Lee JW, Kim YS, Jeong SH, Kim YS, Yim HJ, Kim BH, Lee CK, Park CK, Park SH. Clinical features and treatment efficacy of peginterferon alfa plus ribavirin in chronic hepatitis $\mathrm{C}$ patients coinfected with hepatitis B virus. Korean J Hepatol. 2011;17:199-205.

29. Atalay Ma, Gokahmetoglu S, Aygen B. Genotypes of hepatitis B virus in Central Anatolia, Kayseri, Turkey. Saudi Med J. 2011;32:360-363.

30. Liu CJ, Chuang WL, Lee CM, Yu ML, Lu SN, Wu SS, Liao LY, Chen CL, Kuo HT, Chao YC, Tung SY, Yang SS, Kao JH, Liu CH, Su WW, Lin $C L$, Jeng YM, Chen PJ, Chen DS. Peginterferon alfa-2a plus ribavirin for the treatment of dual chronic infection with hepatitis B and C viruses. Gastroenterology. 2009;136:496-504.e3.

31. Stanzione M, Tonsiello G, lodice V, Macera M, Sagnelli E, Piccinino F, Coppola N. Spontaneous and treatment-induced virological dynamic in the plasma, PBMC and liver tissue in a patient with chronic HBV and HCV coinfection. Infez Med. 2009;17:109-114.

32. Chuang WL, Dai CY, Chang WY, Lee LP, Lin ZY, Chen SC, Hsieh MY, Wang LY, Yu ML. Viral interaction and responses in chronic hepatitis $\mathrm{C}$ and $\mathrm{B}$ coinfected patients with interferon-alpha plus ribavirin combination therapy. Antivir Ther. 2005;10:125-133.

33. Marrone A, Zampino R, D'onofrio M, Ricciotti R, Ruggiero G, Utili R. Combined interferon plus lamivudine treatment in young patients with dual HBV (HBeAg positive) and HCV chronic infection. J Hepatol. 2004;41:1064-1065.

34. Yalcin A, Aygen B, Tekin Koruk S, Koksal I, Karabay O, Tosun S, et al. The characteristics of $\mathrm{HBeAg}$ positive and negative hepatitis B patients in Turkey. In: Omato M, Sarin SK (eds.), The 22nd Conference of the Asian Pacific Association for the Study of the Liver; 2012 Feb 16-19; Taipei, Taiwan. India: Springer; 2012; p. 97-98. 